\title{
JAROLIN JÓZSEF
}

\section{Eljárások drónok felderítésére}

Az utóbbi években ugrásszerüen elterjedtek a pilóta nélküli repülő eszközök ${ }^{1}$, és ez a tendencia vélhetően továbbra sem változik, tulajdoníthatóan az egyre inkább megfizethető árnak, amely egyre bővebb funkcionalitással párosul. Az eszközöket nagyrészt magáncélra, hobbiszinten használják, de mind nagyobb mértékben alkalmaznak speciális, feladatorientált eszközöket (ábra).

Az észak-amerikai drónpiac forgalmának várható alakulása (2013-2024; millió amerikai dollár)

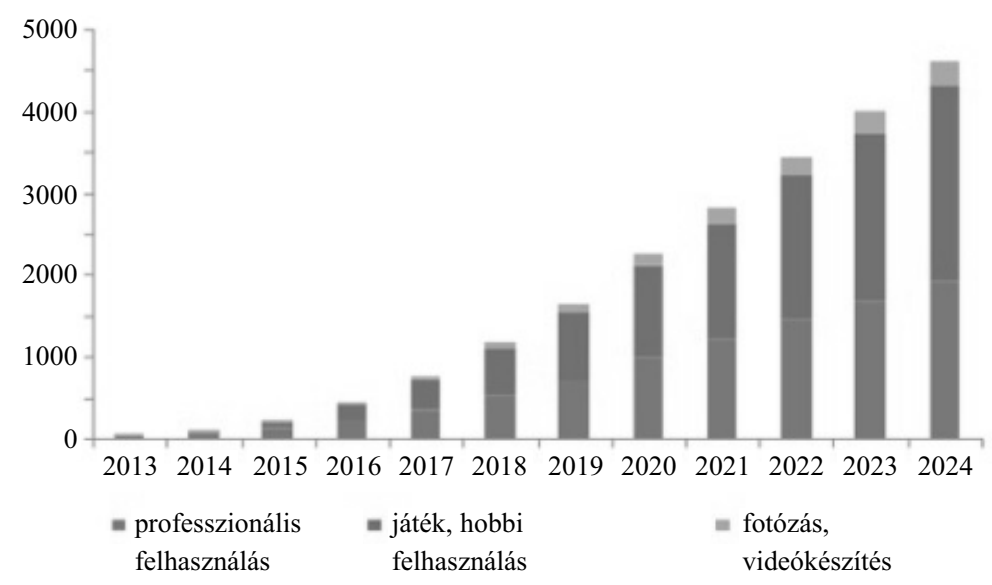

Forrás: http://www.grandviewresearch.com/industry-analysis/consumer-drone-market

Gyakorlati példák is alátámasztják, hogy a drónok jó, illetve rossz ügyek szolgálatába is állíthatók, és a leghasznosabb képességeket a legártalmasabb célokra is lehet használni. Természetesen a drónok használhatóságának sokrétüsége alapjaiban is veszélyeket rejt magában, a nem megfelelően képzett

\footnotetext{
1 A továbbiakban: „drón”, egyaránt alkalmazva az UAV (Unmanned Aerial Vehicle, pilóta nélküli légi jármű): olyan légi jármü, amely repülését, a légtérben való közlekedését a fedélzeten lévő személyzet nélkül végzi és UAS (Unmanned Aerial System, pilóta nélküli légijármü-rendszer): a pilóta nélküli légi jármüvet, annak földi vezérlö/irányító állomását, a jármüvön elhelyezett hasznos terhet és a két pont közötti adatkapcsolatot, irányítást, telemetriát magában foglaló rendszer fogalmak helyett.
} 
pilóták, illetve esetleges minőségi problémákból eredő meghibásodások okán. Belátható azonban, hogy ezek az eszközök könnyen alkalmazhatók kifejezetten ártó szándékkal is. Az elterjedtségből eredő tömegtermelés miatt az áruk kifejezetten megfizethető, így a velük elkövetett káros cselekmények (illegális migráció támogatása, csempészet, terrorcselekmény robbanóanyaggal, tömegpánik-okozás, személyisérülés-okozás) meglehetősen gazdaságosan kivitelezhetők, a böséges funkcionalitás pedig könnyebben végrehajthatóvá teszi az elkövetést.

\section{Károkozási lehetőségek}

A következőkben felsorolt esetekben közös pont, hogy a drónok képességeinek kihasználását állítják az elkövetendő cselekmények szolgálatába. Ezek közül a legfontosabbak a

- kis, feltünésmentes méret;

- repülési, így nagy mobilitási képesség;

- megbízhatóság;

- hasznos teher cipelésének képessége;

- képalkotási lehetőségek.

Egyértelmü, hogy ezek a képességek külön-külön is, kombinálva még inkább egyszerüvé, hatékonyabban kivitelezhetővé teszik a károkozást. Külön kiemelendő, hogy a távolról vezérlés (az eszköz és az irányító személyének elválása) sok esetben a drón, és így az elkövetendő cselekmény személyhez kötését is megnehezíti. A károkozás típusai a következők:

Gondatlan veszélyeztetés: alapvetően a többitől eltérő cselekvési forma, ebben az esetben nem feltétlenül domináns tényező az ártó szándék. Kevés tudással, nem megfelelő tapasztalattal, esetleg hanyagul történő reptetés következtében előállhat gazdasági kárral, esetlegesen személyi sérüléssel járó baleset.

Kiemelt létesitmény elleni támadás, anyagi vagy erkölcsikár-okozás: az adott létesítmény (repülőtér, kritikus infrastruktúra, katonai létesítmények stb.) megfigyelése, müködésének megzavarása ugyanúgy lehet cél, mint a létesítménnyel szembeni károkozás. Könnyen megérthető, hogy a tilos vagy korlátozott helyeken történő reptetés által okozott veszélyhelyzet illetve baleset katasztrófához is vezethet.

Rendezvény megzavarása, pánikkeltés: történhet tudatosan, pánikkeltési, illetve médiabeli reakciót kiváltó okból, figyelmetlenségből, hanyagságból 
egyaránt, hasonló következményekkel. Bármelyik valósul is meg, nem nehéz elképzelni, hogy egy tömegrendezvény esetén egy kisebb károkozás is kelthet pánikot, amelynek hatását a tömeg jelentősen felerősíti. Ehhez elegendő, ha egy tömegbe zuhanó drón személyi sérülést okoz, ami a tömegből kontrollálhatatlan menekülést válthat ki.

Csempészet (drog-, fegyver-, cigaretta-, kommunikációseszköz-, löfegyver-): a repülési hatótávolság és teherhordási képesség növekedésével a drónok ideális eszközévé váltak ennek a tevékenységnek. Kisebb súlyú (néhány kilogramm), nem engedélyezett, vagy kifejezetten tiltott eszközök/áruk szállítása könnyen megvalósítható ily módon. Ez föként határon való átjuttatást vagy örzött intézménybe történő bejuttatást jelent.

Felderités és képrögzités: ebbe a kategóriába értendő a néha a személyiségi jogok megsértésével is együtt járó képek és videók készítése, egyúttal események, objektumok megfigyelése is. Veszélyességi szempontból ehhez kapcsolódhat, a cselekmény esetleges lelepleződésekor a megfigyelt személy vagy csoport drónnal szembeni agresszív fellépése (tüzelés éles lőfegyverrel, így a drónban vagy annak környezetében okozott kár). Mindamellett szintén óhatatlan a károkozás, ha „katasztrófaturista típusú” felhasználás esetén az elkövető a védelmi egységek (tüzoltó-, mentőhelikopter) repülö eszközeit akadályozza.

Rádiófrekvenciás, illetve egyéb technikai zavarás: a károkozás legszofisztikáltabb, nem is sürün alkalmazott módja. Olyan kis méretü eszköz szállítása, majd terítése, amely képes valamilyen szolgáltatás megzavarására. Ezek lehetnek

- rádiófrekvenciás zavaró, amely akár teljesen ellehetetleníti a rádióforgalmazást, így egyebek között akár a telefonforgalmat (hosszú ideig nem fenntartható az energiaszükséglet miatt, ami a drón fedélzetén véges);

- technikai zavaró vagy szennyező anyagok célba juttatása - például széntartalmú anyagok szórása, amely a radarok elvakítására szolgál, egy következő dróntámadás előkészítése céljából;

- szén- vagy más vezetőszálakkal zárlatokozás, az elektromos hálózat müködésének szabotálása érdekében.

Löfegyverek alkalmazása: nehezen kivitelezhető eljárás, mivel meg kell oldani a visszarúgás, hátrasiklás kérdését, ráadásul a lőfegyver és a fedélzeten tárolt löszer súlya és mérete is korlátozó tényező. 
Preciziós rögtönzött robbanóeszköz célba juttatása hasznos teherként: a lőfegyverhez képest alkalmazásának sokkal nagyobb az esélye, a következők miatt:

a) a robbanóeszköz megépítése sokkal kevesebb szaktudást igényel;

b) a drón precíz vezérlése, így az eszköz célba juttatása nagyobb esélyt ad a sikeres végrehajtásra és a menekülésre is;

c) nem kell kifürkészni a cél útvonalát, nem kell semmit telepíteni vagy álcázni.

Vegyi, biológiai, radioaktív hasznos teher célba juttatása: ezek már kis menynyiségben is veszélyes anyagok, így a súly és a méret nem jelent korlátozó tényezőt. Szinte észrevétlenül, nagy távolságról célba juttatható, és a légtérben való eloszlás miatt nagy területen képes kárt okozni. A kár mértékét a terített anyag határozza meg, akár jelentős élőerő-veszteséget vagy pszichológiai hatást okozva.

\section{Drónfelderítés, -elhárítás}

A drónok jelentette új veszélyforrás természetes módon magával vonja az ellene való védekezés kialakulásának módozatait. A veszély mértékét egyre több érintett szerv, valamint gyártó cég is felismerte, kezdetben ez utóbbiak a szakterületüknek megfelelő eszközök kifejlesztését hajtották végre (radart gyártó cég drónokra specializált radart, rádióvevő készüléket gyártó cég rádiós megoldást készített). A cégek később rájöttek, hogy egyenként, a veszély összetettségéből adódóan csak - nem elégséges - részvédelem kialakítására képesek, ezért erre szakosodott rendszerintegrátor cégek bevonásával, több cég termékéből alkottak komplex védelmi rendszereket.

\section{Felderitési metódusok}

Az eljárások célja a drónok közelben történő működésének felismerése, lehetőség szerint lokalizálása, valamint a veszélyesség fokának esetleges meghatározása. A következőkben összefoglalom, milyen eljárások alkalmazhatók a feladat-végrehajtásban, amelyek egyrészt kiegészítik egymást, másrészt megerösítik egymás adatait.

Akusztikus felderítés - a metódus alapelve, hogy mikrofonokkal (mikrofonokból álló hálózattal/ráccsal/mezővel) ellenőrzik a környezetben észlelhető hangteret, és a drónokra (rotorokra) jellemző hangkép észlelésekor kelet- 
kezik riasztás. A felderítési metódus esetén a drónok meghajtása a fő szempont, hiszen belátható, hogy egy kereskedelmi forgalomban kapható, kis méretü multirotoros gép kisebb hangintenzitás keltésére alkalmas, mint egy gázturbinás hajtású, így az észlelési távolság kisebb. Az akusztikus szenzorok néhány száz méteres hatótávolsága mindenképpen korlátozó tényező. Fontos továbbá, hogy lakott területen történő alkalmazásukkor a környezeti zajok mennyire befolyásolják a müködés hatékonyságát.

Radarfelderítés - az eljárás alapelve, hogy a radar által kibocsátott magas frekvenciás sugárzás esetén a szilárd tárgyak visszaverő közegként viselkednek, a visszavert jel irányából és az eltelt időből meghatározható az adott visszaverő közeg, esetünkben a drón elhelyezkedése, mozgási iránya és sebessége. Ennél a felderítési metódusnál fő tényező a drón mérete és anyaga. A nagyobb méret alapesetben nagyobb visszaverő felületet eredményez (speciális esetben a felületet sok éllel és csúccsal tagolják, így visszaverési paramétereit szándékosan rontják a radarral történő nehezebb észlelés érdekében), amely megkönnyíti az észlelést. Érthető módon radarral könnyebb egy nagy, merev szárnyú légi eszköz detektálása, mint egy kis méretü, multirotoros gépé. Az esély utóbbiaknál is fennáll, mivel a rotorok környezetében kialakuló elektromágneses tér is visszaverö közeg. Anyagfelhasználást tekintve a speciális rádiófrekvenciás elnyelő anyagokból felépített vagy ilyen jellegü festékkel kezelt drón észlelése nehezebb radarral, mivel ezek akadályozzák, illetve részben elnyelik a rádióhullámok visszaverődését.

Rádiós felderítés - a módszer alapelve a távvezérlő és a drón közötti rádióforgalmazás detektálása (vezérlőjel és/vagy videojel), ennek alapján az eszközök esetleges lokalizálása. Hátránya, hogy ha a drón nem manuálisan távvezérelt (autonóm navigációjú, GPS-koordináták alapján repülő eszköz), rádiósan inaktív, így nincs kisugárzott, detektálható jele, ezért rádiós úton nem lehet felderíteni. Ebből látható, hogy ennél a felderítési metódusnál elsődleges a drón vezérlésének típusa (bár kevésbé elképzelhető, de nem kizárt, hogy egy autonóm módon repülő drón videojelet sugározzon vissza). Az eljárás előnye, hogy a rádióhullámok minden irányú terjedése magával vonja azt is, hogy bármely irányból fel is deríthető, ehhez „csak” a rádiós rálátásnak kell megvalósulnia, ami egy levegőben lévő tárgy esetén kilométeres távolságból is müködik.

Optikai felderítés - az eljárás alapelve a légtér kamerákkal történő megfigyelése, az abban történő változások, mozgások észlelése esetén a térrész pontosabb (nagyított, képfeldolgozó algoritmusokkal megtámogatott) ellenőrzése a mozgás okának beazonosítása céljából. Természetesen rossz látási 
viszonyok (éjszaka, köd, szürkület) esetében történő feladat-végrehajtásnál előtérbe kerülhet az infrakamerák alkalmazása. A módszer fő kritériuma a drón mérete, valamint sebessége. Fontos megjegyezni, hogy erre az eljárásra negatív befolyással lehetnek az időjárási viszonyok, mindamellett a repülö objektumról, az esetleges hasznos teherről ez szolgálhat a legrészletesebb információval.

\section{A felderitési metódusok különbségei}

Az ismertetett eljárások közötti fő különbség a hatótávolság. Míg fizikai rálátás esetén a radarjelek és a rádióhullámok kilométerekről is hatékonyan detektálhatók, addig például az akusztikus vagy optikai szenzorok csupán pár száz méterről hatékonyak. Az erősebb védelmi rendszereknek éppen ezért van komplex felderítöképességük. Távolból történő észlelésre leginkább radart és/vagy rádiós eszközöket, míg közelebbi beazonosításra optikai berendezéseket vetnek be, így többszintü felderítést valósítanak meg (az első szinten - radar, rádió - nem állapítható meg, hogy a drón milyen, mekkora, hordoz-e hasznos terhet).

Fontos kiemelni továbbá, hogy amíg a radar és a rádiós szenzor reális időn belül 360 fokos lefedettséget képes nyújtani, a távollátó kamerák esetén a belátható szög ennél jóval kevesebb. Egy radar vagy rádiószenzor által észlelt jel esetén azonban az optika irányba fordítása pontosabb beazonosítást, precízebb sebességmeghatározást tesz lehetővé.

Az egyes eljárások alkalmazási feltételeinek különbsége teszi szükségessé komplex rendszer alkalmazását, és ezáltal a hatékonyabb védelem megteremtését. Egy rádiósan nem kommunikáló, autonóm módon repülő jármü esetén a rádiós szenzor önmagában semmit sem ér, ugyanakkor a vele párban alkalmazott radar felderítheti a légtérben megjelenő eszközt. Egy speciálisan kialakított vagy nagyon kis méretü drón radarral történő felderítése nehézkes, azonban ha rádiós vezérlésü, akkor a rádiószenzor detektálja. Az optikai érzékelők alkalmazása minden esetben pontosabbá teszi a konkrétabb eszköz, illetve elhelyezkedés beazonosítását, esetlegesen információt szolgáltathat annak ártó szándékú voltáról (hordott teher).

A komplex rendszer másik fő erőssége, hogy az egymást támogató alkotóelemek egységet alkotnak. A radarral történő észlelés vagy rádiós detektálás hatására az optikai szenzor emberi beavatkozás nélkül irányba fordul és a célkövetés is megvalósul, így nagyságrendekkel megnöveli az azonosítás hatékonyságát. Komplex rendszer nélkül, a detektálás után az optikával történő 
célkeresést manuálisan kell végrehajtani, megtalálni a repülő eszközt. Ugyanez igaz az eszköz elhárítására is, a detektálás után nemcsak az optika, hanem a zavaróegység is irányba fordul, így teremthető meg a célzott, csak a drónra irányzott zavarás, amely komplex rendszer nélkül szintén manuális beavatkozást igényel. Napjainkban a drónok óránkénti ötven-száz kilométer sebességre képesek, ami azt jelenti, hogy a gép másodpercenként tizenöt-huszonöt métert tesz meg, ebből következően a beavatkozás esetében kritikus tény az idő, amely nem engedi meg az emberi beavatkozásból és döntésből származó késlekedést. Szintén fontos tényező, hogy a felderítő rendszer komplexitása tovább növelhető kockázatelemző modul alkalmazásával. Ennek funkciója, hogy az egyes szenzorokról érkező adathalmaz összefüggéseiből következtetéseket von le, ezzel segítve és felgyorsítva a döntés meghozatalát. Például egy nagy sebességgel közelítő (radar- és rádiószenzorok alapján), terhet cipelö (optika), nagyobb méretü drónt a rendszer veszélyesebbnek ítél, mint egy mikroméretü, lassú eszközt.

\section{Elháritási metódusok}

Egy drón feladat-végrehajtásának megakadályozására sokféle megoldás létezik, kockázatmentes megakadályozására azonban jóval kevesebb. Ennek a kettősségnek az oka, hogy az elhárítási megoldások a drón cselekedetének befolyásolására szolgálnak, miközben a környezetet nem veszik figyelembe. Nem foglalkoznak - mert tökéletes megoldást nem tudnak nyújtani - azzal, hogy a drón esetleges lezuhanása milyen következményekkel jár, milyen fizikai károkat, esetleg személyi sérüléseket okoz. Egy kritikus infrastruktúra védelménél nem feltétlenül szükséges számolni ezekkel a tényezőkkel, mivel a védendő érdek túlmutat ezen, illetve az objektumok környezete is legtöbbször lehetővé teszi az ettől való eltekintést. Belvárosi környezetben egy tömegrendezvény esetén azonban ezektöl a járulékos következményektől nem lehet eltekinteni.

Rádiós zavarás: az eljárás alapelve, hogy a nemkívánatos jel frekvenciáján egy nagyobb jelet sugározunk. A nemkívánatos jel drónok esetében a vezérlőjel, vagy a navigációs müholdról a drónhoz érkező jel $\left(\mathrm{GNSS}^{2}\right)$ lehet. Egyszerübb a szóba jöhető frekvenciasávok teljes zavarása (nem konkrét frekvenciák, hanem nagyobb frekvenciaterek), ami viszont a közelben talál-

2 Globális navigációs múholdrendszer (Global Navigation Satellite Systems), az egész Földre kiterjedő, müholdakon alapuló navigációs rendszer általános meghatározása. 
ható WLAN-hálózatok müködését is zavarhatja. Célirányosabb megoldás a drón vezérlőjeléből vett minta irányított visszasugárzásával történő zavarás. Zavarás esetén a drón viselkedése kiszámíthatatlan, beépített védelmi funkcióitól függően „hazatér”, lezuhan, vagy lebeg.

Drónelfogó háló: az alapelv, hogy a drón belegabalyodik a rá kilőtt hálóba, a rotorok így fizikailag nem képesek mozgásban tartani. Ezzel kapcsolatosan jókora nehezítő tényező, hogy a célzás egy nagy sebességgel és valójában az irányítás miatt kiszámíthatatlanul mozgó céltárgy esetén nem egyszerü. Az eszköz maximum néhány száz méter távolságból hatásos, mindamellett siker esetén a drón lezuhanása, esetleg ernyővel történő leereszkedése továbbra is okozhat károkat.

HPEM (High Power Electro Magnetics): az eszköz nagy teljesítményü elektromágneses impulzuslökettel a drón vezérlőelektronikáját, ezáltal magát a drónt teszi müködésképtelenné maximum háromszáz méter távolságból. Ennél az eljárásnál egyértelmüen kijelenthető, hogy siker esetén a drón lezuhan.

GNSS Spoofing: az eljárás alapján megfelelő teljesítményszinttel hamis GNSS-jeleket sugároznak, ezáltal a drón hamis pozíciókat érzékel. Ha a kisugárzott pozíciók folyamatosan kis eltéréssel követik egymást, akkor az autonóm módon repülő drón elméletileg megfelelő földrajzi pontra irányítható, gyakorlatilag lassan eltávolítható a védett térrésztől. Az eljárás hátránya, hogy csak autonóm módon repülö drónok esetében hatékony, előnye, hogy ezeknél a drón a célterülettől eltávolítható a lezuhanás kockázata nélkül.

Távvezérlés átvétele: a metódus alapelve a drón hamis vezérlési utasításokkal való ellátása rádiós úton, így befolyásolva az útvonalát, repülését, müködését. A megfelelő hamis vezérlési utasítások elóállításához az eszköz teljes mértékü beazonosítása szükséges, ez teszi ugyanis lehetővé a vezérlési algoritmus azonosítását, ennek megfelelően a helyes utasítások alkalmazását. Mivel a vezérlési algoritmusoknak több fajtája létezik, egy hatékonyan müködő rendszernek az összeset ismernie kell (adatbázis folyamatos frissítése) a drón pontos típusának meghatározásán felül. Ez az eljárás összetettségét, bonyolultságát tekintve nem lesz meghatározó a közeljövőben.

Megsemmisités: bár a Nemzetbiztonsági Szakszolgálat feladataival nem összeegyeztethető, de a teljesség igénye miatt célszerü szerepeltetni a repülő eszközök lőszerrel, rakétával, lézerrel, egyéb módokon történő fizikai megsemmisitését, amely inkább katonai felhasználásban, illetve kritikusinfrastruktúra-védelem esetében elfogadható eljárás.

Elözetes tervezés: drónfelderítés, -elhárítás esetén kiemelten fontos az előzetes tervezés. Ennek a fázisnak ki kell terjednie a szenzorok megfelelő el- 
helyezésére, egyúttal a célterület környezetében szükséges meghatározni azokat a zónákat is, amelyeken az elhárítás végrehajtható, azaz ahol a drón által elkövetett cselekményből kialakuló, vagy az esetleges lezuhanásából eredő károk minimalizálhatók. Nem nehéz belátni, hogy például egy kiemelt objektum védelmére fixen telepített rendszer esetében ez egyszeri feladat, míg tömegrendezvények biztosítására alkalmazott eszközöknél mindig az alkalomhoz, helyszínhez mérten kialakítandó. Utóbbi esetben fontos kiemelni, hogy az elhárító eljárások nagy része a drón kiszámíthatatlan viselkedését vagy lezuhanását okozza, így az ezzel járó kockázatok felmérése kötelező és szükségszerü, a rezsimszabályok megalkotásával együtt. A tervezés folyamán kell meghatározni a végrehajtáshoz szükséges szenzorok, valamint az elhárításhoz szükséges berendezések számát. A nehezen védhető helyszínek, ahol a biztonsági zónák a védett területtől messze vannak, nagyban befolyásolhatják ezeket a darabszámokat.

\section{Nemzetközi kitekintés}

A nagyvilágban nagyon sok gyártó készít szenzorokat, hatalmas minőségbeli különbségekkel. A gyártók felismerték az üzleti lehetőséget, amelyet a drónok nagymértékủ elterjedése, illetve az általuk keltett veszély mértéke jelent, így kifejezetten ellenük készített eszközök gyártásába fogtak. Ha a komplexitást is a fő kritériumok közé soroljuk, azaz a szenzorok együttes müködését, valamint a döntés-elösegítő algoritmusokat is az alapkövetelmények közé helyezzük, akkor már kevesebb potenciális rendszert találunk. Természetesen ott készítenek drónfelderítö/-elhárító rendszereket, ahol a gyártókapacitás, a gazdasági körülmények és az elméleti lehetőségek is rendelkezésre állnak.

A teljesség igénye nélkül, inkább csak kitekintésként, három komplex rendszert említenék meg.

Az egyik az angol AUDS $^{3}$ (Anti-UAV Defence System) rendszer, amely radart, optikát, valamint rádiós zavarót alkalmaz. A radarrendszer a felderítésért felel, és észlelés esetén a közös platformra épített optikát és zavarót irányba forgatja. A környezeti tényezők alapján a nappali vagy az infrakamera végzi az azonosítást, szükség esetén pedig végrehajtható a vezérlés és/vagy a GNSS zavarása.

3 http://www.auds.com 
A német Guardion ${ }^{4}$ rendszert jellemzi jelenleg az egyik legbőségesebb alkotóelem-kínálat. A rádiófrekvenciás iránymérőre, radarra, optikai és akusztikus szenzorokra épülő felderítést rádiós zavarással, nagy teljesítményü elektromágneses impulzuson alapuló müködésképtelenné tétellel, valamint kézi és gépjármüre szerelhető hálóvetővel megvalósított elhárítással kombinálták.

A Hologarde ${ }^{5}$ rendszer felderítési szempontból szintén a radar, rádiófrekvenciás, valamint optikai szenzorok egységét alkalmazza.

\section{Összegzés}

A drónok rendeltetésszerủ és megfelelő használata előremutató és modern alkalmazási lehetőségeket teremt, mindamellett a védelmi szektornak nem szabad megfeledkeznie a rosszindulatú alkalmazás lehetőségéről sem. Már léteznek a drónok felderítésére alkalmas, hatékony eszközrendszerek meglehetősen borsos beszerzési áron -, de az alkalmazásuk a feladathoz illesztett kiemelt tervező-, előkészítő munkát igényel. Mivel a drónok nagy sebessége miatt az adott beavatkozás időkritikus tevékenység, valamint az esetlegesen okozott károk felismerése és meghatározása okán felelősségteljes feladat, így az elökészítés, a szükséges erőforrások felmérése és a felkészülés úgyszintén idő- és anyagiforrás-igényes folyamat.

Az Nemzetbiztonsági Szakszolgálatot korlátozott mértékủ rádiós drónfelderítő és -elhárító képesség jellemzi. Az észlelőképesség az úszó-világbajnokságon már bizonyított: a rendezvények helyszínein tizenhét nap alatt kilencvenkét drón müködését észleltük.

4 http://drohnenabwehr.de/en/home/

$5 \mathrm{http}: / /$ hologarde.com 